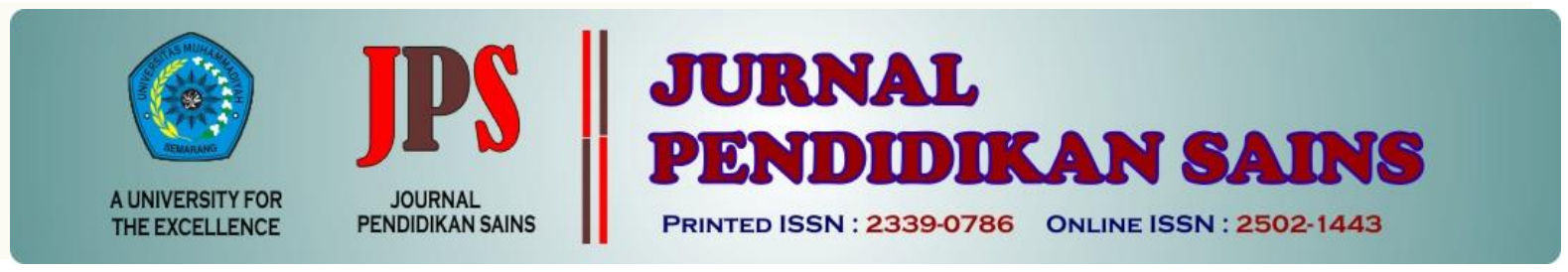

http://jurnal.unimus.ac.id/index.php/JPKIMIA

\title{
DEVELOPMENT TEXTBOOK WITH PROBLEM POSING METHOD TO IMPROVE SELF REGULATED LEARNING AND UNDERSTANDING CONCEPT
}

\author{
Eni Fariyatul Fahyuni ${ }^{1}$; Moch. Bahak Udin By Arifin ${ }^{1}$; Dwi Nastiti ${ }^{2}$ \\ ${ }^{1}$ Faculty of Islamic Studies. Universitas Muhammadiyah Sidoarjo \\ ${ }^{2}$ Faculty Psychology, Universitas Muhammadiyah Sidoarjo
}

\begin{tabular}{ll}
\hline \multicolumn{2}{l}{ Article history } \\
\hline Submission & $:$ 2019-03-16 \\
Revised & $:-$ \\
Accepted & $:$ 2019-04-05
\end{tabular}

Keyword:

Text book, problem posing, self regulated; concept

\begin{abstract}
This research to: (1) assess textbook validity, (2) assess textbook practicality, and (3) measure textbook effectiveness to improve self regulated learning and understanding concepts in 2 Porong Junior high school. The development textbook with problem posing method refers to the Dick and Carey models. Data collected with questionnaires, observations, and pretest posttest which analyzed by t-test. The following results of textbook 3.88 (valid). The result of textbook 3.87 (practical). The results of textbooks 3.89 (effective). The textbook developed can be an alternative teaching material to support student learning.
\end{abstract}

\section{Pendahuluan}

Heat is a science learning material, which difficult for teachers to deliver messages because they are abstract. Temperature is a measure in heat. While heat is the quantity of heat absorbed and released by an object (Fahyuni \& Sholeh, 2018:5). Heat and temperature are prerequisite material that teachers must instill to their students before they learn heat energy. Energy such as strong people have a lot of energy, people energetic, energy pushes ships in the sea, energy batteries of turning motors and so on. Temperature and heat material coverage large so that students need to conduct scientific investigations to improve process skills and understanding concept (Fahyuni, Rusijono, \& Masitoh, 2018: 114).

Problem posing aimed introducing to the problems that conceptually, procedurally with problem solving. Howe (2006: 57) students will not be able to build their own understanding without social learning. Vygotsky in Slavin (2006: 77) states that cognitive abilities persons result process of social interaction. Therefore relating complex problems improve communication, interaction, and courage of students in arguing and expressing various. For that learning activities students must be given flexibility in learning, interact with learning resources to build knowledge from their learning experiences. Self regulated learning positions as active learning who can organize their new information through accommodation and assimilation (Slavin, 2006: 76).

The characteristic of science learning distinguished by teacher applying teaching process be able to fulfill completion minimum criteria in the school. Teacher combined with question and answer method on the problem solving. The learning process make it who do not like taught by the teacher. The results

*Corresponding Author:

$\begin{array}{ll}\text { Nama } & \text { : Eni Fariyatul Fahyuni1 } \\ \text { Lembaga } & \text { : Universitas Muhammadiyah Sidoarjo } \\ \text { Email } & \text { : eni.fariyatul@ umsida.ac.id }\end{array}$


percentage of learning students at second grade junior high school 2 Porong, see Table 1.

Table 1. Daily Repeat Student

\begin{tabular}{ccccc}
\hline Class & \multicolumn{2}{c}{ Total } & $\%$ & Total \\
\cline { 2 - 5 } & $\begin{array}{c}\text { Achiev } \\
\text { ed }\end{array}$ & $\begin{array}{c}\text { Not } \\
\text { achieve } \\
\mathrm{d}\end{array}$ & $\begin{array}{c}\text { Achieve } \\
\mathrm{d}\end{array}$ & $\begin{array}{c}\text { Not } \\
\text { achieve } \\
\mathrm{d}\end{array}$ \\
\hline VIIa & 1 & 33 & $2.94 \%$ & 97,1 \\
\hline VIIb & 0 & 34 & $0 \%$ & $100 \%$ \\
\hline \multicolumn{5}{c}{ Average } \\
\hline
\end{tabular}

Table 1 shows student VIIa class have not completed learning outcomes and only 1 student is completed with an average learning incompleteness $97.1 \%$. Class VIIb students have not complete $100 \%$. Thus help students' learning difficulties, teacher must design to help increase learning abilities. Based on the table 1 can be concluded that students have difficulty answering multiple choice questions and essay forms on temperature and heat material from the percentage and indicator. The following show Table 2.

Table 2. Temperature and Heat Material

\begin{tabular}{llc}
\hline No & Indikator & $\begin{array}{c}\text { Prosentase } \\
\text { Kesulitan }\end{array}$ \\
\hline 1 & Thermometer & $55 \%$ \\
\hline 2 & Expansion & $76 \%$ \\
\hline 3 & Changes in substance & $47 \%$ \\
\hline 4 & Heat movement & $74 \%$ \\
\hline & Average & $63 \%$ \\
\hline & The results
\end{tabular}

student learning in the material temperature and heat is $63 \%$. The highest percentage of learning difficulties is expansioan $76 \%$ in determining concepts and implementation of science in life. Teaching method considered practical and does not require many ideas and thoughts preparing learning device. As a result learning centered on educators while students are not accustomed being active in learning process.

This triggers level of student learning, which difficulties concepts on material (Susanto, 2012). Bruner (Nirwana et al., 2006: 11) discovery learning can build knowledge. Fahyuni, Rusijono, Masitoh (2019: 3) states teachers designing by guided inquiry worksheets can stimulate process skills and understanding concepts. The problem posing method formulate the problem and students research.

Baharullah research (2013: 23) show that application of the problem posing method aimed at self-confidence, challenges, critical and creativity to recognize natural phenomena in the surrounding environment. According to Upu (2003: 10) science learning using the problem posing method can be applied individually or in groups or in pairs. The results of research Rohaeti, Budiyanto, and Sumarmo (2014: 8) self regulated learning (SRL) make students able to evaluate and manage their learning more effectively and efficiently. The application of SRL able to activate and generate interest students practicing problems solving. Akmil, et al (2012: 2) state students provide flexibility in building and constructing meaning for they have learned. The use of textbook related delivering student in the 21st century, development science and technology. This scientific literacy should be development of life

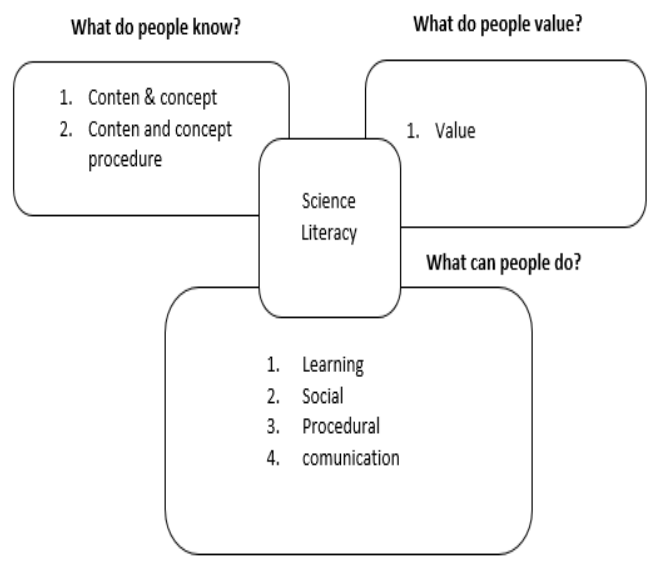

skills for the students. Graber explains with scientific literacy.

Figure 1. Literasi Sains Graber

(Holbrook \& Rumnikmae, 2009)

The developing textbook with problem posing method conducting an investigative activities that have not been implemented. For this reason, teachers or developers in this case need to take advantage of the use of BAS IPA must be in accordance with the characteristics of students and the school context to improve self-regulated learning of students to learn from nature independently and be able to understand the science concepts they learn.

\section{Method of Research}

This research and development $(\mathrm{R} \& \mathrm{D})$ for design learning systems with model Dick and Carey (2009: 7). Dick \& Carey model carried out involving learning such as teachers, students, teaching, and learning process.

The development of textbook with problem posing method that require solutions refer to educational technology. Educational 
technology is not technology learning process, but facilitate learning to improve performance to designing situated for meaningful learning.

\section{Time and Research Place}

This research was conducted at Porong 2 Junior High School one semester starting July to December 2018 for students transition period so that they need a lot of guidance from teachers and tutors.

\section{Research Subject}

The research subject were students at Porong 2 Junior High School in class VIIa and VIIb. The subjects of this study were divided into two groups (nonequivalent pre-test posttest control group design), group A applied textbook with problem posing method, group B applied textbook with conventional methods.

This research carried out considering: 1) dissemination of textbook with problem posing method to students' literacy, 2) the institutions and teachers develop textbook, and 3 ) the distance of schools are not too far away can facilitate the coordination of teachers and student needs in developing textbook.

\section{Development Procedur}

The developing textbook with problem posing method referring Dick \& Carey model (2009: 7). The development is presented in Figure 2.

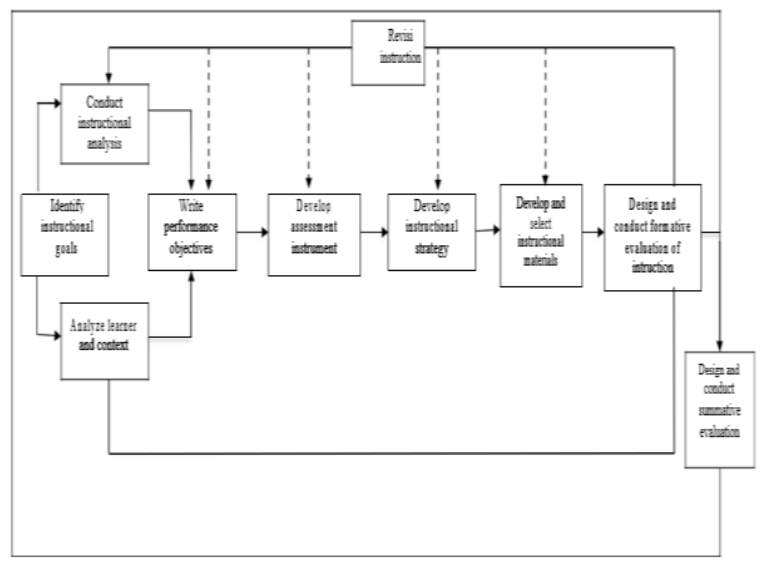

Figure 2. Dick dan Carey Model (The Systematic Design of instruction, 2009:7).

Dick \& Carey model (2009:16);

1. Identify learning goals

Identify problems expected solutions students in learning. Identify learning goals adjusted content or material, characteristics of students, and the context in which learning carried out (Smith \& Ragan, 2005)
2. Conduct learning analysis

Conduct learning analysis formulating of skills, knowledge, and attitudes that can be achieved on the science learning objectives.

3. Conduct analysis and learning context

Analysis characteristic students and learning context can be done simultaneously. Analysis context of learning can be learned to their capacity. Analysis characteristics students at Porong 2 Junior High School preliminary knowledge students, academic level, and learning style. The analysis students and learning context was closely related textbooks to be used.

4. Write performance objective

Identification characteristics and learning context. The developer can formulate specific objectives of learning beginning of learning.

5. Develop assessment instrument.

The specific learning objectives have been formulated in learning tests and practice observation to assessment self regulated learning and understanding concepts based on defined learning goals.

6. Develop learning strategy

Developing learning strategies related to formulating specific learning indicators and learning strategies to achieve specific objectives on the following factors: 1) based on a strong theoretical foundation, 2) findings produced in previous research, 3) media and the teaching methods, 4) learning content or content, 5) student characteristics and the learning context.

7. Develop and select learning materials

Developing and select learning materials cannot avoid. Learning materials such as internet facilities for students looking for data, science literature. Other supporting materials needed in learning activities surrounding environment that are easily and obtained practical activities in school

8. Design and conduct formative .

Formative evaluation was carried out by the developer aimed various data strengths and weaknesses of the development of textbook with problem posing method. Formative evaluation as input material to revise textbook. Formative evaluation includes: 1) individual evaluation (one to one evaluation), 2) small group evaluation, 3) field evaluation in learning class (field trial). The expert validate textbook with problem posing, consisting of: 1) learning design, 2) 
learning materials and 3) education practitioners.

9. Revision of learning

The revision textbook with problem posing method is not carried out an improvement on textbook draft, but overall components involved to improve textbook developed.

10.Design and conduct evaluasi sumatif

This summative evaluation is not done or involves developer personally but rather an independent assessment team to tests the effectiveness of the product in the market. Summative evaluation stage is not included in the process of developing the Dick and Carey model (2009: 67)

\section{Data Colection}

This research and development involved two groups (nonequivalent control group design), without random pre-test and post-test (Creswell, 2016: 132).

Data collection of this study include data on validity, practicality, and effectiveness.

1. The validity of textbook

The validity of textbook filled by two expert. Suggestions and expert then revised and validity on individuals, small group evaluation, and field evaluation.

2. The practical of textbook

The practicality instrument on textbook observations. According to Sudjana (2011: 32). Practical assessment observers, including: 1) content / material presented, 2) delivery of information, and 3) learning strategies.

\section{The effectiveness of textbook}

Effectiveness data is as follows. a) practicum observation, b) practical activities by two observers. The practicality criteria consists of 4 (four) check lists, namely: 4 (four) very good, 3 (three) quite good, 2 (two) less, and 1 (one) not good.

The tests are in the form of pretest and posttest in multiple choice. Test refers objectives and standards learning abilities measured in Bloom's taxonomy (Anderson et al., 2001).

\section{Data Analysis}

Data analysis aims to accuracy research and development through aspects validity, practicality, and effectiveness. This analysis on the results validation of science experts, learning media experts, and education practitioners.

Data analysis was carried out by testing individual, small group and field evaluation in the class. The results of the validity analysis, practicality, and effectiveness were revised, among others.

a) Analysis of validity textbook involves media experts, material experts and practitioners. The validation results analyzed referring suggestions from validator.

b) Analysis of practical textbook determine function and readability with problem posing method, including: 1) learning instructions; 2) learning material; 3) learning activities; and 4) valuation techniques.

c) Analysis of effectiveness textbook consists; 1) practicum find out self regulated learning, and 2) test multiple choice measure conceptual understanding.

\section{Results and Discussion}

The results textbook with problem posing method include the validity, practicality and effectiveness products.

1. The results of textbook feasibility with problem posing method show average 3.88 means very valid. The suggestions and input from the validator are: a) textbook is not single resource, but it is available on the internet, teaching aids and others that can support learning resources for students. b) Images and or illustrations textbook clarify the material to be delivered.

2. The results of the practicality textbook with problem posing method from the results of the practicum observations average 3.87 in the excellent category and the results of the questionnaire showed students were easy to understand and construct of their investigations.

3. The results of textbook effectiveness with problem posing method results of pretest group A and group B show Sig (2-tailed) data of 0.200 and 0.160 which means normally distributed. In the homogeneity test, the Sig (2-tailed) value of 0.63 indicates the variance of the distribution of the two groups is homogeneous or the same. The results T-Test showed that the Sig (2-tailed) $0,000<0,05$. This means there are differences in learning outcomes.

4. The results of textbook effectiveness in practical activities between group B and 
group A showed the Sig (2-tailed) value of $0,000<0,05$. This means that differences practicum skills between group B and group A. Textbook effectively improve self-regulated learning in schools.

\section{Conclusions}

Textbook with problem posing method adjust the science concept, students learning dynamic and progress to multitalents and potential. Textbook with problem posing method help students "learning to know", improve "learning to do", make them "learning to be" and make them "learning to live together". Students recognize for self-regulated learning and understanding concepts.

\section{Acknowledgement}

The researcher appreciation student for seventh grade at junior high school 2 Porong, teacher, headmaster, and Universitas Muhammadiyah Sidoarjo as funding continuity of institutional research in development textbook with problem posing method.

\section{References}

Akmil, A.R., Armiati dan Yusmet. (2012). Implementasi CTL dalam meningkatkan Pemahaman Konsep Matematika Siswa. Jurnal pendidikan, 1(1): 24-29.

Anderson, Mahjardi. (2001). A taxonomy for learning, teaching, and assessing (a revision of bloom's taxonomy of education objectives, abridged edition). New York: Longman

Baharullah. (2013) Penerapan Pendekatan Problem Posing Berlatar Pembelajaran Kooperatif Di Sekolah Dasar. Makassar: Jurusan Pendidikan Matematika. Unismuh Makassar.

Creswell. (2016). Research design (pendekatan kualitatif, kuantitatif, dan mixed). Yogyakarta: Pustaka Pelajar.

Dick, W dan Carey, L (2009). The systematic design of instruction. Fifth edition. New Jersey: Pearson Education Inc.
Fahyuni, E.F. \& Sholeh, M. (2018). Kenapa bisa begini, ya? suhu dan kalor. Sidoarjo: Umsida Press.

Fahyuni, E.F., Rusijono, \& Masitoh (2018). The guided inquiry worksheet: growing with scientist in Indonesia middle school. Proccedings of the 1st International Conference on Intellectuals' Global Responsibility (ICIGR 2017). Januari 2018. Sidoarjo: Universitas Muhammadiyah Sidoarjo.

Fahyuni, E.F., Rusijono, \& Masitoh (2019). The Guided-Inquiry-Worksheet stimulating Process Skills and Concept Understanding in Indonesia Junior High School. Asian Journal of Education and Social Studies. 3(1): 110, 2019; Article no.AJESS. 44645

Howe, A. (2006). Development of science concept within vygotskian framework science education. Singapore: John Willy and Son. http://www.21st Centuryskill.org

Rohaeti, E. , Budiyanto, A.M., \& Sumarmo, U. (2014). Enhancing students' mathematical logical thinking ability and self regulated learning through problem based learning. International Journal of Education, 8 (1), 53-63.

Slavin, R.E. (2006). Psikologi Pendidikan. Teori dan Praktik. Edisi ke-sembilan Jilid I. Jakarta: PT Indeks.

Sudjana, Nana. (2009). Penilaian proses hasil belajar mengajar. Bandung: PT Remaja Rosdakarya.

Susanto. (2012). Studi komparasi Penggunaan Metode Pembelajaran TGT dan STAD Terhadap Prestasi Belajar Siswa Pada Materi Pokok Hukum Dasar Kimia. Jurnal Pendidikan Kimia, 1(1), 36-39.

Upu, Hamzah. (2003) Problem Posing dan Problem Solving dalam Pembelajaran Matematika. Bandung: Pustaka Ramadhan. 